\title{
Size composition and sex ratio of Anadara tuberculosa and Anadara similis in a mangrove reserve from the northwest of Ecuador
}

\author{
Estructura de tallas y proporción sexual de Anadara tuberculosa y Anadara similis \\ en una reserva de manglares al noroeste de Ecuador
}

Luis Flores $^{1}$ and Roberto Licandeo ${ }^{2}$

1'Investigación de Recursos Bioacuáticos y su Ambiente, Instituto Nacional de Pesca, Letamendi 102 y La Ria, P.O. Box 09-01-
15131, Guayaquil, Ecuador. Iflores@inp.gob.ec
${ }^{2}$ Center for Quantitative Fisheries Ecology, Old Dominion University, 800, West 46th Street, Norfolk, United States of America

\begin{abstract}
Shell length frequency distribution (SLFD) and sex ratio of a subpopulation of the mangrove cockles Anadara tuberculosa and Anadara similis were analyzed from natural beds in the Cayapas-Mataje Ecological Mangrove Reserve, Ecuador. The SLFD was different between sexes for both species; females were larger than males. Subpopulations of $A$. tuberculosa and $A$. similis were dominated by females throughout the year. The overall sex ratio was 2.6:1 (female: male), although with variations in the monthly samples, from 1.2:1 to 5.9:1 in A. tuberculosa and 1.9:1 to $5.3: 1$ in A. similis. Possibly, these results may be due to differential growth rate between sexes and environmental factors along the year.
\end{abstract}

Key words: Shell length, mangrove cockles, natural beds

\section{INTRODUCTION}

Mangroves are the dominant intertidal vegetation in subtropical and tropical estuarine systems (Duke 1992) and support essential ecological functions (Twilley 1988). One of the direct benefits to humans that mangroves provide is support for artisanal fisheries (e.g., cockles, crabs and fish).

The mangrove cockles (also called ark-shells or arkcockles) fisheries of the genus Anadara spp. are one of the most important commercial mollusks along the Pacific coast from Mexico to Peru, showing a geographic distribution along the coast of $6350 \mathrm{~km}$ approximately (Mackenzie 2001). Three species are harvested: Anadara tuberculosa (Sowerby, 1833), Anadara similis (Adams, 1852) and Anadara grandis (Broderip \& Sowerby, 1829), although A. tuberculosa is the most abundant. In South America, little information exists in the international literature concerning its fisheries and biology (e.g., Mackenzie 2001, Cruz \& Borda 2003, Borda \& Cruz 2004).

At the present, Ecuador is one of the countries with the largest number of cockle fishermen in Latin America about 5000 (Mackenzie 2001). Anadara tuberculosa is commonly known as 'concha prieta' or 'concha hembra', whereas Anadara similis as 'concha mica' or 'concha macho'. Esmeraldas, at the north of Ecuador, has the highest percentage of cockle harvesters or 'concheros'. In this locaty it is found the Cayapas-Mataje Ecological
Mangrove Reserve (REMACAM) (Fig. 1), wich is considered as the last remaining fully functional and pristine mangrove ecosystem in Ecuador. REMACAM is located in the delta formed by the estuary of the CayapasSantiago-Mataje Rivers, at the northwest of Esmeraldas on the border of Colombia; it has a surface area of 53200 ha, of which 32250 ha are terrestrial habitats and 18000 ha are mangroves. Ocampo-Thomason (2006) estimated that $79 \%$ of the Ecuadorian cockle gatherers can be found in REMACAM and that $85 \%$ of the local inhabitants in RECAMAM have fishing and cockles gathering as a principal source of income and subsistence.

Basic information detailing cockle population structure, e.g., shell length frequency distribution (SLFD) and sex ratio, related to the biology and the effects of change in temporal scales is virtually non-existent for the above species on the Pacific Coast of Ecuador. Also, little is known about the impact of fisheries on the mangrove cockle beds implying the need to study unexploited beds. The goal of the present study was to investigate the population structure of Anadara tuberculosa and Anadara similis in beds where fishery was suspended almost for two years (considered in this study as unexploited beds) plus the time of this study (one year). In order to evaluate temporal scale variations of population structure of these 


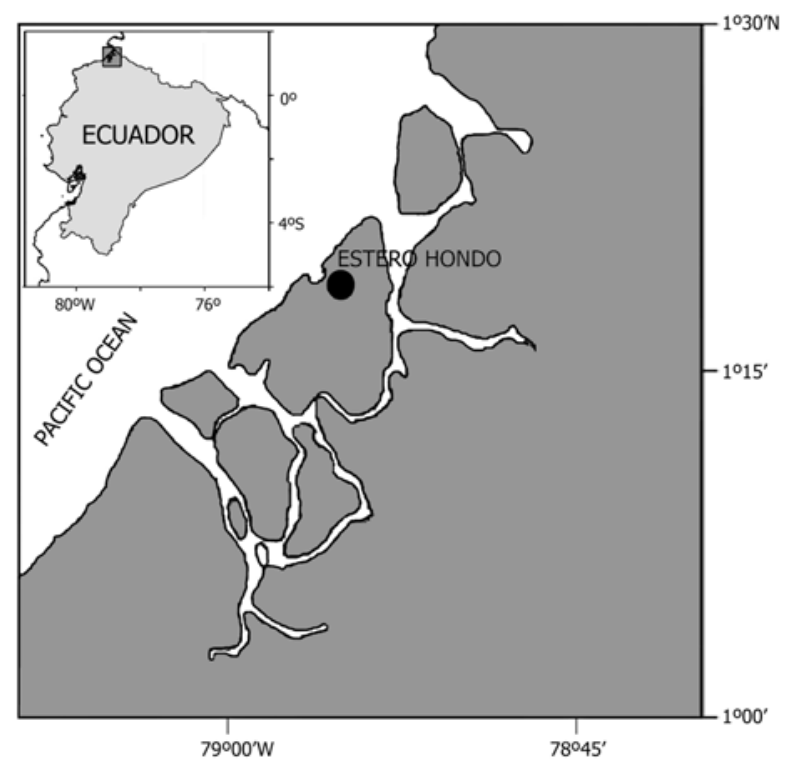

Figure 1. Geographic location of the Mangrove Reserve CayapasMataje (REMACAM) in the North of Ecuador and sampling site / Localización geográfica de la Reserva de Manglares Cayapas-Mataje (REMACAM) en el norte de Ecuador y el sitio de muestreo

species, we specifically describe the intra-annual population variability between the two main seasons of coastal Ecuador (dry and rainy).

\section{Material AND Methods}

Samples were collected in Estero Hondo at REMACAM (Fig. 1) from February 2001 to January 2002, based on a simple random sampling in the intertidal zone during medium -to- low tide. Cockles were collected by hand with the help of a cockle harvester. The sampling extended across to the two main season in Ecuador, the dry season (December to May) and rainy season (June to November). A total of 1997 specimens between the two species were obtained throughout the year (1199 females, 465 males and 333 indeterminate). These were separated by species in the laboratory. For all cockles, shell length (SL, mm) was measured from the anterior edge of the shell to the posterior edge using a $0.05 \mathrm{~mm}$ precision caliper and then recorded. The sex was determined based on a macroscopic observation of gonad mass according to Cruz (1984a, b).

SL data were grouped into 3 and $6 \mathrm{~mm}$ length class intervals for Anadara similis and Anadara tuberculosa respectively, in order to obtain the shell length frequency distribution (SLFD) for each season and as an overall sample (year). Mean SL and standard error (SE) were estimated for each month and the Kruskal-Wallis test was used to evaluate differences among months. To assess the effect of season, a t-test was used. The SLFD of each species was compared using the two samples KolmogorovSmirnov test. The sex was considered in all analyses. The Chi-square test was used to test significant deviations from the expected sex ratio 1:1 (female: male) for each month, season and across the annual sample. All analyses were performed in the $\mathrm{R}$ environment ( $\mathrm{R}$ Development Core Team 20071).

\section{Results AND Discussion}

\section{SHELL LENGTH FREQUENCY DISTRIBUTION}

In Anadara tuberculosa females, the SL ranged between 29.8 to $82.2 \mathrm{~mm}$, while the males ranged between 31.1 to $71.1 \mathrm{~mm}$ (Fig. 2). The mean SL of females ( $48.44 \pm 0.22$ $\mathrm{SE} \mathrm{mm})$ was larger than males $(46.88 \pm 0.37 \mathrm{SE} \mathrm{mm})$ for the overall sample $(\mathrm{t}=3.65, \mathrm{df}=620, P<0.0001)$. A strong variability within the year was observed in the mean SL of A. tuberculosa females as shown by a Kruskal-Wallis analysis $(\mathrm{H}=56.37, \mathrm{df}=11, P<0.0001)$. However, those differences were not observed in males $(\mathrm{H}=12.56, \mathrm{df}=$ 11, $P>0.05)$.

The comparison of mean SL between female and male cockles within the dry and rainy seasons also showed differences (dry: $\mathrm{t}=2.45, \mathrm{df}=324, P<0.05$; rainy: $\mathrm{t}=$ $2.59, \mathrm{df}=297, P<0.05)$. However, between seasons, the mean SL of the females of the rainy season was larger than the dry season $(\mathrm{t}=3.34, \mathrm{df}=819, P<0.001)$. This pattern was not observed in males $(\mathrm{t}=1.77, \mathrm{df}=327, P>0.05)$.

The comparison of SLFD between the sexes within each season showed differences only in the rainy season $(\mathrm{D}=0.151, P<0.05)$. The SLFD in males did not show differences between seasons in Anadara tuberculosa $(\mathrm{D}=0.132, P>0.05)$. However, differences were found in the SLFD between seasons for females ( $\mathrm{D}=0.137, P<$ 0.001).

In Anadara similis, the SL varied between 35.4 to 61.3 $\mathrm{mm}$ and 30.5 to $58.2 \mathrm{~mm}$ in females and males, respectively (Fig. 2). The mean SL of the females (46.84 $\pm 0.29 \mathrm{SE}$ $\mathrm{mm})$ was larger than that of the males $(43.99 \pm 0.49 \mathrm{SE}$ $\mathrm{mm})$ for the overall sample $(\mathrm{t}=5.03, \mathrm{df}=203, P<0.0001)$. However, in A. similis there was no evidence of variability

${ }^{1} \mathrm{R}$ Development Core Team. 2007. R: A language and environment for statistical computing. R Foundation for Statistical Computing, Vienna, Austria. ISBN 3-900051-07-0, URL http://www.Rproject.org. 


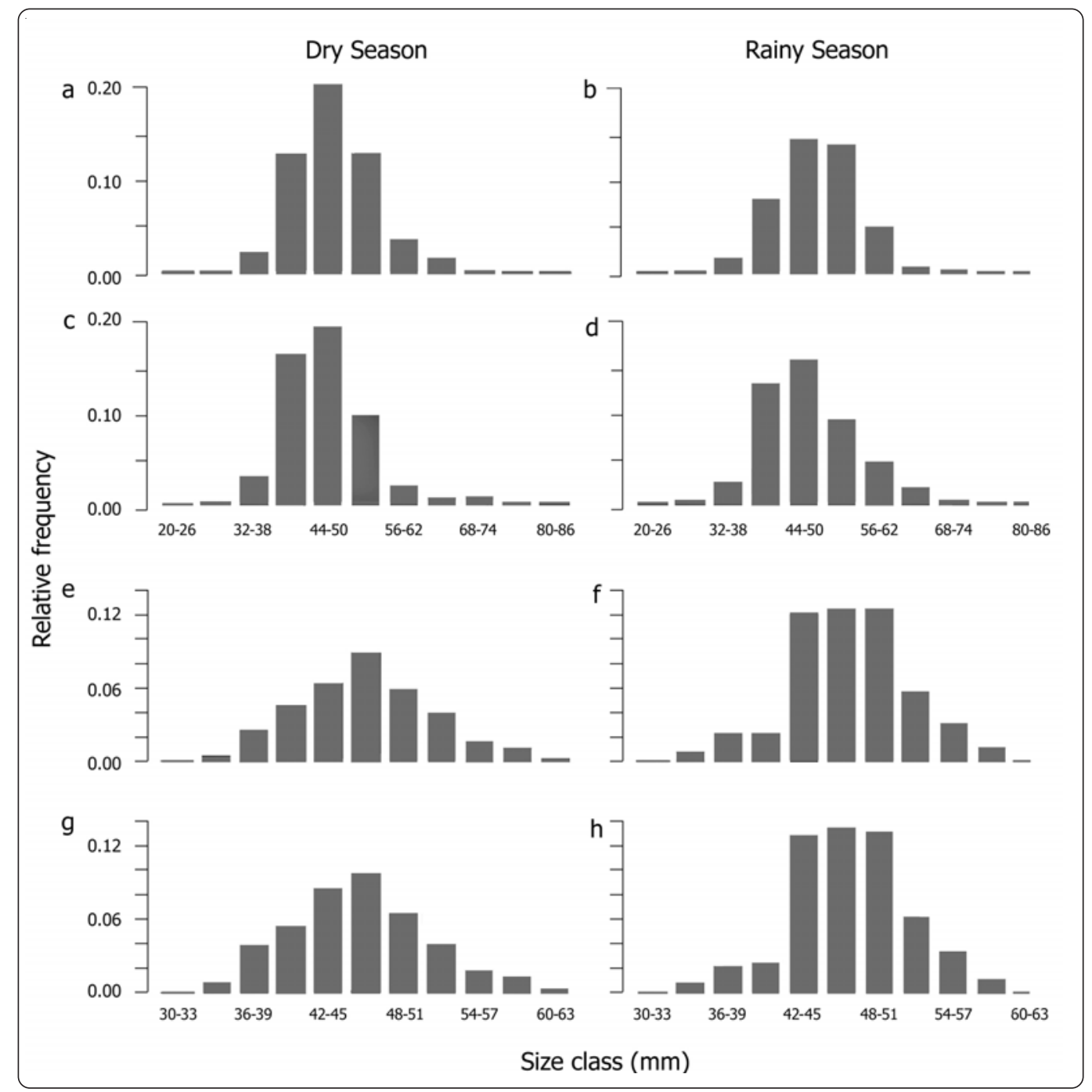

Figure 2. Shell length frequency distribution by sex and season to Anadara tuberculosa (females: $a$ and b; males: $c$ and d) and Anadara similis (females: $e$ and g; males: $g$ and $h$ ) in Estero Hondo, REMACAM / Distribución de frecuencia de longitud de concha por sexo y estación para $A$. tuberculosa (hembras: a y b; machos: c y d) y Anadara similis (hembras: e y $\mathrm{g}$; machos: $g$ y $h$ ) en el Estero Hondo, REMACAM

in the mean SL within the year in females or in males according to the Kruskal-Wallis analyses (females: $\mathrm{H}=$ 9.75, df $=11, P>0.05$; males: $\mathrm{H}=18.42$, $\mathrm{df}=11, P>$ $0.05)$.

In the dry and rainy season the mean SL cockles differed between males and females in each season period (dry: $\mathrm{t}=$ 3.25, df $=65, P<0.05$; rainy: $\mathrm{t}=3.98$, df $=135, P<$ $0.0001)$, but there were no differences in the SL between seasons for either females $(\mathrm{t}=1.03, \mathrm{df}=247, P>0.05)$ or males $(\mathrm{t}=1.06$, $\mathrm{df}=75, P>0.05)$.

The SLFD also showed differences between females and males within seasons (dry: $\mathrm{D}=0.3272, P<0.05$; rainy $\mathrm{D}=0.2247, P<0.05)$. The differences discovered between seasons in the SLFD males of Anadara similis ( $D=0.2703$, $P=0.041$ ) were at the margin of the probability limit and this could be considered as weak. However, the differences were not clearly found in females ( $\mathrm{D}=0.1137, P>0.05)$.

The mean SL observed in Anadara tuberculosa and Anadara similis was larger than the recently reported by Silva \& Bonilla (2001), Borda \& Cruz (2004), PérezMedina (2005), and Stern-Pirlot \& Wolff (2006) considering site average. This can be explained by the fact that the surveyed bed was without exploitation for almost three years. This confirms what Stern-Pirlot \& Wolff (2006) point out regarding harvest pressure as a factor which directly affects shell length composition, especially when the exploitation rate is too high.

Another good example is one reported by Baqueiro (1980) at the end of the 1970's, in which several swamps were exploited and others were left undisturbed. His study found a variation in the mean SL (56 to $72 \mathrm{~mm}$ ) among eight mangrove swamps surveyed. This emphasizes the 
importance of considering the differential exploitation rate to which those species could be subjected on some spatial scale (e.g., small-scale); what have been suggested for Anadara tuberculosa (Stern-Pirlot \& Wolff 2006).

This study observed Anadara tuberculosa between 26.4 and $82.2 \mathrm{~mm}$ SL. This is different from the SL reported in other countries, for example, a range of $16-118 \mathrm{~mm}$ was reported by Baqueiro (1980), 22-94 $\mathrm{mm}$ by Baqueiro et al. (1982), 18-82 mm by Borda \& Cruz (2004), 11-71 mm by Stern-Pirlot \& Wolff (2006) and 32-72 mm by Guilbert (2007). In Anadara similis, the SL range observed in this study was between 30.1 and $63.4 \mathrm{~mm}$. This reveals that the beds have a different range of SL and that could be due to variations in population and fisheries processes. Differences in SLFD has been also assessed by site (see Baqueiro 1980, Stern-Pirlot \& Wolff 2006), but sex has not been considered. Thus, this study represents the first where this factor has been taken into account.

Significant differences in SLFD between sexes in both mangrove cockle species were found in the whole sample. Also, differences in SLFD were found by season in Anadara similis and only in the rainy season for Anadara tuberculosa. These results suggest that differences in some population processes and previous effects of fishing mortality could exist. Variations in growth between sexes could explain the differences observed in this study's SLFD and is also possibly supported by the differences found in the mean SL of A. tuberculosa and A. similis. It is relevant to consider growth rate variations in sedentary and semisedentary bivalves because these are greatly influenced by environmental and biological factors, vary from population to population and from individual to individual (Caddy 1989).

Temporal variations in both species have been little studied (e.g., Baqueiro et al. 1982) and the factors that could have some effect are poorly understood. According with this, it is not clear why only the females of Anadara tuberculosa would be affected by this seasonal pattern. It is necessary to conduct further investigations that can clarify the factors that are controlling the dynamics of the SLFD and the temporal and spatial scales at which this operates.

\section{Sex RATio}

The sex ratio analysis showed that Anadara tuberculosa females outnumbered males in the overall sample, with an overall sex ratio of 2.57:1 (Female: Male) (Table 1). The monthly samples showed a strong variability within the year in the sex ratio; from 1.20:1 (January 2002) to 5.91:1 (February 2001). Also, the sex ratio was dominated by females mainly in dry and rainy seasons (Table 1).

The sex ratio analysis in Anadara similis also showed that females outnumbered males in the overall sample and

Table 1. Female and male mangrove cockle numbers in the sampling of Anadara tuberculosa and Anadara similis. Sex ratio (Female/Male) and Chi-square analysis with probability. Asterisks indicate no significant differences / Número de conchas hembras y machos en el muestreo de Anadara tuberculosa y Anadara similis. Proporción sexual (Hembras/Machos) y análisis Chi-cuadrado con su nivel de probabilidad. El asterisco indica diferencias no significativas

\begin{tabular}{|c|c|c|c|c|c|c|c|c|c|c|}
\hline \multirow[t]{2}{*}{ Date } & \multicolumn{5}{|c|}{ Anadara tuberculosa } & \multicolumn{5}{|c|}{ Anadara similis } \\
\hline & Female & Male & Sex ratio & $\mathrm{X}^{2}$ & Probability & Female & Male & Sex ratio & $\mathrm{X}^{2}$ & Probability \\
\hline $02 / 2001$ & 130 & 22 & 5.91 & 76.74 & $P<0.00001$ & 18 & 7 & 2.57 & 4.84 & $P<0.05$ \\
\hline $03 / 2001$ & 73 & 33 & 2.21 & 15.09 & $P<0.001$ & 17 & 4 & 4.25 & 8.50 & $P<0.01$ \\
\hline $04 / 2001$ & 105 & 30 & 3.50 & 41.67 & $P<0.00001$ & 26 & 6 & 4.33 & 12.50 & $P<0.001$ \\
\hline $05 / 2001$ & 112 & 47 & 2.38 & 26.57 & $P<0.00001$ & 12 & 6 & 2.00 & 2.00 & $P<0.10^{*}$ \\
\hline $06 / 2001$ & 55 & 18 & 3.06 & 18.75 & $P<0.001$ & 13 & 4 & 3.25 & 4.76 & $P<0.05$ \\
\hline $07 / 2001$ & 89 & 24 & 3.71 & 37.39 & $P<0.00001$ & 29 & 14 & 2.07 & 5.23 & $P<0.05$ \\
\hline $08 / 2001$ & 84 & 42 & 2.00 & 14.00 & $P<0.001$ & 52 & 18 & 2.89 & 16.51 & $P<0.0001$ \\
\hline $09 / 2001$ & 53 & 33 & 1.60 & 4.65 & $P<0.05$ & 29 & 14 & 2.07 & 5.23 & $P<0.05$ \\
\hline $10 / 2001$ & 47 & 26 & 1.80 & 6.04 & $P<0.05$ & 30 & 14 & 2.14 & 5.81 & $P<0.05$ \\
\hline $11 / 2001$ & 72 & 23 & 3.13 & 25.27 & $P<0.00001$ & 29 & 15 & 1.93 & 4.45 & $P<0.05$ \\
\hline $12 / 2001$ & 46 & 28 & 1.64 & 4.38 & $P<0.05$ & 21 & 4 & 5.25 & 11.56 & $P<0.001$ \\
\hline $01 / 2002$ & 24 & 20 & 1.20 & 0.36 & $P>0.10^{*}$ & 33 & 13 & 2.54 & 8.69 & $P<0.01$ \\
\hline Total & 890 & 346 & 2.57 & 239.43 & $P<0.00001$ & 309 & 119 & 2.60 & 84.35 & $P<0.00001$ \\
\hline
\end{tabular}


by season with a overall sex ratio of 2.60:1 (F:M) (Table 1). Also, the monthly samples showed a strong variability within the year in the sex ratio; from 1.93:1 (November 2001) to 5.25:1 (December 2001). These results differs from previous studies over Anadara tuberculosa (Cruz 1984a, Silva \& Bonilla 2001, Pérez-Medina 2005), which found a ratio close to 1:1. In Anadara similis, Cruz (1984b) and Silva \& Bonilla (2001) also found a sex ratio close to 1:1.

The dominance of females for other species of Anadara have also been reported (Yankson 1982, Mzighani 2005). Some reasons may explain this. However, one of the reasonable arguments supporting this fact is a sexual reversion from males to females since sex change is common in bivalves (Mzighani 2005). Pérez-Medina (2005) observed that a small portion of A. tuberculosa in his study had shown hermaphroditism and for that reason he reported this species as a casual hermaphrodite. On the other hand, A. similis has not had reports of hermaphroditism yet. Casual hermaphroditism as a reproductive characteristic has been reported in other species like A. senilis (Yankson 1982) and A. antiquata (Mzighani 2005). Recently, Afiati (2007) found a rare occurrence of hermaphrodites in A. granosa and A. antiquata, suggesting a sequential protandric hermaphroditism due to the unbalanced sex ratio derived from the size frequency distribution.

It is possible that a grade of hermaphroditism occurs in Anadara tuberculosa and Anadara similis, and this would explain the strong variability within the year of the sex ratio in both species. In this study, change in sex ratio across length classes was not evaluated. According to Mzighani (2005), the dominance of females across length classes could be indicative of protandrous hermaphroditism, what is supported by the reported recently by Afiati (2007).

To demonstrate protandrous hermaphroditism, future research should consider the use of histological analysis across the shell length class. If this hypothesis is supported, the hermaphroditism may result from several factors such as stress, an unstable hereditary sex determining mechanism, seasonal environmental factors or nutrients (Mzighani 2005). In addition, another factor that should be considered is pollution. It can act as an endocrine disruptor in bivalves affecting the reproductive behavior in several ways (e.g., Gagné et al. 2003); therefore, it could have ecological significance at the population level (Depledge \& Billinghurst 1999). The previous statements should be considered in future investigations.

\section{ACKNOWLedgments}

This study is part of the undergraduate thesis of LF at the Universidad de Guayaquil (Ecuador), supported by the Instituto Nacional de Pesca (INP) and the Fondo Ecuatoriano Populorum Progressio (FEPP). LF is grateful to Nikita Gaibor (INP), Juan Moreno (INP) and Edgar Lemos (FEPP) for their support with funding aspects. This paper started during our stay as graduate students at the Departamento de Oceanografía in the Universidad de Concepción (UDEC), and we are thankful for the scholarships of CONICYT and the Direccion de Postgrado of UDEC. Our gratitude to Meredith Gober and Liliana Alencastro for improving the English text and Billy Ernst for his help with Figure 1, as well as to Yahira Piedrahita (Directora - INP) for her support with funding for the publication of this manuscript. Finally, LF wants to especially thank Doña Delfida (conchera de Santa Rosa REMACAM) for her hospitality and collaboration during the fieldwork. Without her, data collection would not have been possible.

\section{LITERATURE CITED}

Afiati N. 2007. Hermaphroditism in Anadara granosa (L.) and Anadara antiquata (L.) (Bivalvia: Arcidae) from central Java. Journal of Coastal Development 10: 171-179.

Baqueiro E. 1980. Population structure of the mangrove cockle Anadara tuberculosa (Sowerby, 1833) from eight mangroves swamps in Magdalena and Almejas Bays, Baja California Sur, Mexico. Proceedings of the National Shellfisheries Association 70: 201-206.

Baqueiro E, M Muciño \& R Merino. 1982. Análisis de una población de pata de mula Anadara tuberculosa sujeta a explotación intensiva en la Bahía de La Paz, Baja California Sur, México. Ciencia Pesquera 3: 75-82.

Borda CA \& R Cruz. 2004. Reproducción y reclutamiento del molusco Anadara tuberculosa (Sowerby, 1833) en el Pacifico Colombiano. Revista de Investigaciones Marinas 25: 185-195.

Caddy JF. 1989. Recent developments in research and management for wild stocks of bivalves and gastropods. In: Caddy JF (ed). Marine invertebrate fisheries: their assessment and management, pp. 665-700. John Wiley and Sons, New York.

Cruz RA. 1984a. Algunos aspectos de la reproducción en Anadara tuberculosa (Pelecypoda: Arcidae) de Punta Morales, Puntarenas, Costa Rica. Revista de Biología Tropical 32: 45-50.

Cruz RA. 1984b. Algunos aspectos reproductivos y variación mensual del índice de condición de Anadara similis (Pelecypoda: Arcidae) de Jicaral, Puntarenas, Costa Rica. Brenesia 22: 95-105. 
Cruz R \& CA Borda. 2003. Estado de explotación y pronóstico de la pesquería de Anadara tuberculosa (Sowerby, 1833) en el Pacifico Colombiano. Revista de Investigaciones Marinas 24: 221-230.

Depledge MH \& Z Billinghurst. 1999. Ecological significance of endocrine disruption in marine invertebrates. Marine Pollution Bulletin 39: 32-38.

Duke NC. 1992. Mangrove floristic and biogeography. In: Robertson AI \& D Alongi (eds). Tropical mangrove ecosystems, pp. 63-100. American Geophysical Union, Washington.

Gagné F, C Blaise, J Pellerin, E Pelletier, M Douville, S Gauthier-Clerc \& L Viglino. 2003. Sex alteration in softshell clams (Mya arenaria) in an intertidal zone of the Saint Lawrence River (Quebec, Canada). Comparative Biochemistry and Physiology Part C 134: 189-198.

Guilbert A. 2007. State of the Anadara tuberculosa (Bivalvia: Arcidae) fishery in Las Perlas Archipelago, Panama. Master of Science thesis, School of Life Sciences, Heriot-Watt University, Edinburgh, 73 pp.

MacKenzie CL Jr. 2001. The fisheries for mangrove cockles, Anadara spp., from Mexico to Peru, with descriptions of their habitats and biology, the fishermen's lives, and the effects of shrimp farming. Marines Fisheries Review 63: 1-39.

Mzighani S. 2005. Fecundity and population structure of cockles, Anadara antiquata L. 1758 (Bivalvia: Arcidae) from a sandy/muddy beach near Dar es Salaam, Tanzania.
Western Indian Ocean Journal of Marine Science 3: 221225.

Ocampo-Thomason P. 2006. Mangroves, people and cockles: Impacts of the shrimp-farming industry on mangrove communities in Esmeraldas Province, Ecuador. In: Hoanh CT, TP Tuong, JW Gowing \& B Hardy (eds). Environment and livelihoods in Tropical Coastal Zones: managing agriculture-fishery-aquaculture conflicts, pp. 140-153. CAB International, Wallingford.

Pérez-Medina D. 2005. Biología reproductiva de Anadara tuberculosa (Bivalvia: Arcidae) en el Estero Santo Domingo, B.C.S., México. Tesis de Maestría en Ciencias, CICIMAR, México, 86 pp.

Silva A \& R Bonilla. 2001. Abundancia y morfometría de Anadara tuberculosa y A. similis (Mollusca: Bivalvia) en el Manglar de Purruja, Golfo Dulce, Costa Rica. Revista de Biología Tropical 49(Supl. 2): 315-320.

Stern-Pirlot A \& M Wolff. 2006. Population dynamics and fisheries potential of Anadara tuberculosa (Bivalvia: Arcidae) along the Pacific coast of Costa Rica. Revista de Biologia Tropical 54(Suppl. 1): 87-99.

Twilley RR. 1988. Coupling of mangroves to the productivity of estuarine and coastal waters. In: Jansson BO (ed). Coastal-offshore ecosystem interactions, pp. 155-180. Springer-Verlag, New York.

Yankson K. 1982. Gonad maturation and sexuality in the West African bloody cockle Anadara senilis (L). Journal of Molluscan Studies 48: 294-300.

Recibido el 8 de febrero de 2010 y aceptado el 29 de julio de 2010 